\title{
The Current Information in Nutrition Therapy of Phenylketonuria
}

\author{
Sabiha Zeynep Aydenk Köseoğlu ${ }^{*}$, Seda Çelikel ${ }^{2}$ \\ 1 İstanbul Sabahattin Zaim Üniversitesi, Sağlık Bilimleri Fakültesi, Beslenme ve Diyetetik Bölümü, İstanbul, Türkiye (ORCID: 0000-0001-7936-8462) \\ 2 İstanbul Gelişim Üniversitesi, Sağlık Bilimleri Yüksekokulu, Beslenme ve Diyetetik Bölümü, İstanbul, Türkiye (ORCID: 0000-0001-6578-980
}

(Illk Geliş Tarihi 14 February 2020 ve Kabul Tarihi 23 March 2020)

(DOI: $10.31590 /$ ejosat.693556)

ATIF/REFERENCE: Köseoğlu, S. Z. A. \& Çelikel, S. (2020). The Current İnformation in Nutrition Therapy of Phenylketonuria. Avrupa Bilim ve Teknoloji Dergisi, (18), 755-761.

\begin{abstract}
Phenylketonuria (PKU) is one of the most common congenital metabolism disorders. In this disease, due to the defect in the phenylalanine hydroxylase enzyme made in the liver, phenylalanine cannot follow the tyrosine pathway and the symptoms of phenylalanine metabolites occur in body tissues, organs and body fluids. Nutritional therapy is applied in the treatment of the disease depending on the type of PKU. The purpose of nutritional therapy is to minimize the amount of phenylalane taken with nutrients and to keep the level of blood phenylale within normal limits. For this reason, a special nutrition program is applied throughout the life from the newborn period. The first step in the diagnosis of PKU is to determine the level of plasma phenylalanine with the blood sample taken from the heel of the newborn. Different types of hyperphenylalaninemias are seen as a result of phenylalanine hydroxylase enzyme and tetrahydrobiopterine (BH4) metabolism disorder. In the formation of BH4 cofactor defects, there is a defect in the metabolism of tetrahydrobiopterin, and its findings are different from classical PKU. In addition to the proper nutrition program, large neutral aminoacids (LNAA) and sapropterin (a synthetic form of BH4) are used in the treatment, according to the results of new studies. In classical PKU, when there is no medical nutrition treatment specific to the disease, many clinical findings such as mental retardation, skin-hair pigmentation disorders, growth retardation, microcephaly, epilepsy, behavioral disorders, hyperactivity and anxiety can be seen. In order for the symptoms associated with PKU to decrease and individuals with PKU to live a healthier life, they should comply with dietary treatment that includes protein-restricted, high-fat and carbohydrate-containing foods except for vegetables and fruits limited from phenylalanine Essential protein sources should be provided with special formulas with added tyrosine and essential amino acids and foods enriched with vitamins and minerals that may be deficient. However, the implementation of an effective nutrition therapy is possible by providing communication between the healthcare team and the family and introducing the disease to the family, and training in the development and treatment of the disease.
\end{abstract}

Keywords: Phenylketonuria, Phenylalanine, Phenylalanine hydroxilase, Tetrahydrobiopterin.

\section{Introduction}

Phenylalanine is an essential amino acid secreted from the liver. Phenylketonuria disease is a disorder caused by the absence or insufficiency of the phenylalanine hydroxylase enzyme that metabolizes phenylalanine and as a result of the accumulation of phenylalanine metabolites in the brain and excretion in the urine. When patients with phenylketonuria were diagnosed in the neonatal period; it has been found that mental retardation and other neurological findings can be prevented with limited nutritional therapy for phenylalanine (Ney et al.,2009).

Phenylketonuria is a hereditary disease, and was discovered in 1934 by Fölling after research on two mentally handicapped children. In the following years, it has been proven that phenylalanine accumulates in the blood and spinal fluids of people with mental retardation and phenylpyruvic acid in urine, and there is no activity of the phenylalanine hydroxylase enzyme (which converts phenylalanine to tyrosine) in their livers. 20 years after the discovery of PKU, Bickel demonstrated the existence of a positive nutrition program that could prevent mental retardation in this disease. With the onset of screening of phenylketonuria in the early $1963 \mathrm{~s}$, mental retardation that can be seen in all children born with phenylketonuria was prevented. The incidence of PKU in the world in general is $1 /$ The frequency in our country varies between 1 / 3.600-1 / 4.000 (Köksal \& Gökmen Özel, 2019).

\footnotetext{
* Sorumlu Yazar: İstanbul Sabahattin Zaim Üniversitesi, Sağlık Bilimleri Fakültesi, Beslenme ve Diyetetik Bölümü, İstanbul, Türkiye, ORCID: 00000001-7936-8462, szaydenk@gmail.com
} 


\section{The Genetic Feature of Patients with PKU}

The mother and father of the child with phenylketonuria have two genes, one of which is normal and one of which is responsible for the production of phenylalanine hydroxylase enzyme. A child who receives defective genes from their parents is born with phenylketonuria. The child who receives a defective gene from his parents carries the disease. However, it does not show any signs of illness. When parents are carriers, the probability of having phenylketonuria in their children is $25 \%$. Therefore, there is a higher risk of disease in consanguineous marriages. Phenylketonuria is a hereditary metabolic disease that can be treated if diagnosed in the neonatal period, otherwise severe mental retardation occurs (Liu et al., 2017).

\section{Diagnosis of the baby with PKU}

When a baby with phenylketonuria is born, it is indistinguishable from a healthy baby. The level of phenylalanine, which cannot be metabolized after the baby's first protein-containing diet, begins to increase in the blood. Brain damage caused by PKU may not usually be noticed by parents in the first months. However, the development problems of the baby started from the first months, either it did not develop or it developed late. If the problem of the baby, who is not able to hold his/her head fully upright, but does not know the mother at the time of two months, cannot be understood in these months, when the brain is brought to the doctor because he/she is unable to sit, walk, talk, be indifferent to the environment or transfer to the doctor, he / she is irreversibly damaged. In addition, as another finding, the urine of these babies smells differently than the healthy ones (the smell of mold). $60 \%$ of the patients have very light hair color and light eye color. Late diagnosis and late treatment may cause brain damage to become irreversible, but many positive behaviors can be developed in these children. In a study of 16 PKU patients who are still normal despite high plasma phenylalanine concentrations, other neurological, psychological and behavioral problems were frequently seen in patients, although intellectual functionality was not relatively affected (van Vliet et al., 2019)

\section{Diagnostic tests of PKU}

In many studies, the presence of mentally handicapped, untreated children with PKU was determined, and in the 1950s, it was observed that Bickel phenylalanine-containing foods were not given to these children and was important for the recovery of the disease. In the following years, amino acid mixtures that did not contain phenylalanine and that would meet the protein requirement of the child were found and it was emphasized that these amino acids should be used in addition to the treatment (Köksal \& Gökmen Özel, 2019). Individuals who do not applied diet therapy have severe intellectual disability, whereas individuals who are on therapy from the early neonatal period have normal intellectual function therefore, it was agreed that this treatment should be started immediately after birth, in the first 20 days. This indicates that the amount of phenylalanine should be measured in the blood of all newborns. (McPheeters et al, 2012).

In the 1960s, Prof. Dr. with the Guthrie Test developed by Robert Guthrie, screening programs have been started to detect the disease in newborn babies in the world. In our country, in 1986, screening tests were started in 80 provinces by taking blood from the heel of newborn babies. Within 24-48 hours of each newborn baby following the first feeding, blood samples are taken on special filter paper, and diagnosis is made by applying various chromatographic methods for plasma phenylalanine (PA) level. Even if the normal phenylalanine level is found in the screening test, if there is a suspicious condition in the families of the babies, blood phenylalanine levels should be re-evaluated within 2-4 weeks after birth. A second type of diagnosis is ironchloride (FeC13) test. It is determined by a green color that disappears after 3-5 minutes by looking at the urine of babies with PKU. Even if the normal phenylalanine level is found in the screening test, if there is a suspicious condition in the families of the babies, blood phenylalanine levels should be reevaluated within 2-4 weeks after birth. A second type of diagnosis is ironchloride (FeC13) test. It is determined by a green color that disappears after 3-5 minutes by looking at the urine of babies with PKU (Ahring et al., 2009; Peate, 2020).

\section{The types of PKU}

Apart from PKU, different types of hyperphenylanlanemias occur due to problems in the metabolism of phenylalanine hydroxylase enzyme or tetrahydrobiopteridine (BH4), the cofactor of this enzyme. Hyperphenylaninemias are divided into 5 groups (Enacan et al., 2019).

\section{Classical PKU}

It is the type of PKU that results from the absence or decrease of phenylalanine (PA) hydroxylase enzyme activity that converts phenylalanine to tyrosine in the liver. Phenylalanine metabolites disrupt normal metabolism, causing brain damage. There are some criteria for diagnosing in classical phenylketonuria: plasma PA levels are high ( $\geq 20 \mathrm{mg} / \mathrm{dl}$ or $1200 \mu \mathrm{mol} / \mathrm{L})$ and the tyrosine levels are normal $(0.55-1 \mathrm{mg} / \mathrm{dl}$ or $54 \mu \mathrm{mol} / \mathrm{L})$; increased metabolites of phenylalanine (a-hydroxyphenylacetic phenylacetic acid, phenyl lactic acid, phenyl pyruvic acid and phenyl acetic acid, glutamine) in urine; plasma level increase by reintroducing the removed phenylalanine; normal level of cofactor tetrahydrobiopterin in plasma. Prognosis is poor if these patients are not treated. Their daily PA tolerances (representing the amount of PA in which blood PA level is kept at approximately 300-400 $\mu \mathrm{mol} / \mathrm{L}$ or 2-6 mg / dl) is less than $20 \mathrm{mg} / \mathrm{kg}$ at the age of 5 (Azaripour \& Abbasi, 2020).

\section{Moderate PKU}

Serum PA level ranges between $900-1200 \mu \mathrm{mol} / \mathrm{L}(15-20 \mathrm{mg} / \mathrm{dl})$, and daily PA tolerance at the age of 5 is about $20-25 \mathrm{mg} / \mathrm{kg}$ (Herenger et al., 2019).

\section{Mild PKU}

It is the lightest type. Serum PA level before treatment does not exceed $15 \mathrm{mg} / \mathrm{dl}(900 \mu \mathrm{mol} / \mathrm{L})$ and PA tolerance is more than 25 $50 \mathrm{mg} / \mathrm{kg}$ at age 5 (Levy et al., 2019).

\section{Mild Hyperphenilalaninemia (nonphenylketonuric hyperphenylaninemia)}

In children with this type of hyperphenylalaninemia, the blood phenylalanine level under the free diet is below $10 \mathrm{mg} / \mathrm{dl}$. Nutritional therapy may not be required in patients in this group (Levy et al., 2019). 


\section{Cofactor Defects}

It is defined as a biochemical defect formed in the cofactor compounds (tetrahydrobiopterin) required for hydroxylation of phenylalanine. In these patients, the activity of the PA hydroxylase enzyme was found to be normal, but the defect in dihydropteridine reductase or dihydropteridine synthetase enzymes required for the synthesis of tetrahydrobiopterine (BH), which is the cofactor of this enzyme. Synthesized from guanosine triphosphate (GTP), BH4 is also the cofactor of the tyrosine and tryptophan hydroxylases required for the biosynthesis of neurotransmitters, dopamine and serotonin (Lichter-Konecki \& Vockley, 2019).

\section{Findings of PKU}

General findings include:

$\checkmark$ Low birth weight, vomiting (early finding)

$\checkmark$ High blood phenylalanine level (normally 2-6 mg/ dl, above disease $15-20 \mathrm{mg} / \mathrm{dl}$ )

$\checkmark$ It is also the precursor of norepinephrine, which plays a role in the transmission of tyrosine nerve impulses formed in the first step of the phenylalanine metabolism. Since there is no tyrosine in its deficiency, synaptic transmission is adversely affected.

$\checkmark \quad$ As the age progresses (over 4 months), the synthesis of lipid, nucleic acid and proteins decreases in the brain as a result of constantly high phenylalanine in the blood. As a result, mental retardation and nervous system symptoms (hyperactivity, aggressive, convulsive seizures), microcephaly may occur in patients.

$\checkmark$ With the increase of phenylalanine in the blood, enzymes of hexokinase and pyruvatkinase are suppressed, glycolysis and oxidative metabolism rate decreases, and thus energy formation decreases.

$\checkmark$ Bad smell in urine and sweat (phenylpyruvate, phenyllactate; phenylacetate)

$\checkmark$ Pigment disorders (light color of hair, skin and eyes due to lack of melanin) eczema and seberoic skin rashes

$\checkmark$ Convulsions that can be seen at any age, hyperkinetism in older children, autistic behaviors (Köksal \& Gökmen Özel, 2019).

\section{Treatment of PKU}

When babies with PKU can be diagnosed in the first days following birth, the findings can be prevented with appropriate nutritional therapy. The only treatment currently applied in phenylketonuria disease is nutrition therapy. It should last a lifetime (Mitchell et al., 2011). Objectives of nutritional therapy:

$\checkmark$ To support keeping the level of phenylalanine in the blood at a level that will ensure normal growth, prevent or minimize brain damage.

$\checkmark$ Phenylalanine, which will not cause hyperphenilalaninemia with diet, and will be sufficient for growth and development (according to PKU type, patient's age, height, weight and blood phenylalanine level, each individual's tolerance is different), protein $(2.2-3.5 \mathrm{~g} / \mathrm{kg} /$ day in infants, providing energy, vitamins and trace elements in the child of play age $1.5-2.2 \mathrm{~g} / \mathrm{kg} /$ day) (Köksal \& Gökmen Özel, 2019).

$\checkmark$ To ensure that the diet of the patient is acceptable in terms of taste diversity, to prevent the diet from being monotonous by means of exchange lists and to ensure its saturation.

$\checkmark$ Ensuring that the patient is not affected by weight loss and other catabolic events during follow-up (the breakdown of body proteins enables the release of phenylalanine and requires the evaluation of the patient's weight impression and energy intake or excessive energy intake).

$\checkmark$ To determine the phenylalanine, protein and energy requirements of the patient, to give the amount of phenylalanine to be given daily in 6-8 meals in infants and in 3 or 4 equal meals in the children's group, to ensure the consumption of natural protein sources and to monitor the intake, As the patient grows, making changes in the scope of the diet and ensuring that he consumes the diet given to him for life (Rocha \& MacDonald, 2016).

$\checkmark \quad$ The dietician and doctor should be educating the patient and his family about the disease, nutritional therapy and amino acid mixtures used, low protein products and exchange lists. In a study investigating the demographic data of children with PKU and the quality of life of their parents and their effect on treatment compliance and the average blood phe level, the average age of the patients whose metabolic control was considered bad was 9.4 years; Mean age of the patients with a good metabolic control was found to be 4.7 years. When the quality of life of the parents of patients with good / bad metabolic control was examined, there was no significant difference between them. It was found that patients between the ages of 0-5 were better compliant with the diet, although it was not statistically significant in compliance with the protein restricted diet and supplementary foods (Bay, 2019).

\section{Energy}

Fats and pure carbohydrates (such as sugar, starch) are important energy sources in nutrition that is poor in phenylalanine. For this purpose, children can be given sugar, honey, jam, molasses, oil, starch, lemonade, linden (with sugar), tea (with sugar) depending on their age. In addition, the use of low protein products with a low protein content, and therefore a low amount of phenylalanine and high energy content, is important in eliminating the energy deficit in these patients. The energy needs of the children, who start to complement nutrition, are met with special flour soups, starchy foods, low protein vegetables and fruits. If the diet is not followed, loss of tissues occurs as a result of insufficient energy intake and malnutrition occurs as a result of tissue destruction. Insufficient energy in the diet causes the breakdown of tissue proteins and the increase in the level of blood phenylalanine by releasing phenylalanine from the tissues (Evans et al., 2019) 


\section{Protein}

In order to control the blood PA level, the natural protein sources in the diet should be limited and the blood PA level should be kept within safe limits in all diagnosed patients with serum phenylalanine level $\geq 6 \mathrm{mg} / \mathrm{dl}(360 \mu \mathrm{mol} / \mathrm{L})$. In the daily feeding program of the child with PKU, foods such as meat, fish, eggs, cheese with high protein and phenylalanine content should not be included. Required for the growth of the child and according to the ability to metabolize, phenylalanine must be met from natural protein sources (such as vegetables, fruits), the remaining protein requirement is not included in phenylalanine or phenylalanine and has low protein content, high energy content, tyrosine and other essential amino acids, vitamins, minerals and It should be obtained from amino acid mixtures enriched with trace elements. PKU patients should be given phe-free formulas and avoid foods rich in protein (eg meat, fish, eggs, standard bread, cheese, nuts and kernels) and foods and beverages containing aspartame. Low-protein natural foods such as potatoes, some vegetables and most cereals can be consumed on condition that they are limited. Some types of food are also available, such as low-protein bread and low-protein pasta (Blau et al., 2010).

In order to keep blood phenylalanine levels within certain limits, at least $80-90 \%$ of the daily protein requirement in infancy and at least $50 \%$ of childhood and adolescence must be met from special amino acid mixtures. Daily amounts of amino acid mixtures can be given in liquid beverages, divided into meals, along with other recommended foods (Concolino et al., 2017).

Amino acid mixtures should be given 8 times a day in the neonatal period, 6 times a day up to one year, and at least 3 equal meals a day in the post-one year period. By taking amino acid mixtures continuously in single and overdose catabolism, oxidative use and urinary nitrogen loss increases and nitrogen deficiency may occur. Amino acid blends without PA are very difficult to take alone, as their taste is poor. These mixtures are used as a food with starch, rice flour, sugar, oil in infancy, and in children who cannot take larger food, fruit lemon juices and sodas are tried to be brought to taste (Durrer et al., 2017).

\section{Phenylalanine}

PA is a essantial aminoacid which can be found in protein foods. PA constitutes $5 \%$ of the amino acids in the protein structure, and since it is an essential amino acid, it is not possible to completely remove it from the diet. A healthy child uses half of the PA that he provides from protein in his daily diet in protein synthesis, and turns the remaining amount into tyrosine (Strisciuglio \& Concolino, 2014).

Diet therapy in PKU should be started in the first 20 days of life. The amount of PA that can be given daily should be adjusted according to blood PA levels $(2-6 \mathrm{mg} / \mathrm{dl}$ or $120-360 \mu \mathrm{mol} / \mathrm{L})$, and the pattern of the diet should be changed according to the growth and development rate by taking blood controls once a week and once a year in the first month of life (Ney et al., 2014).

In the planning of nutritional therapy, it is necessary to first discharge the phenylalanine accumulated in the tissues and body fluids, followed by a diet with no phenylalanine (containing 0 PA) for 3-7 days. Thus, brain destruction can be prevented by decreasing the phenylalanine accumulated in the blood, tissues and urine to normal levels. Targeted values of blood PA levels: less than 6 mg / dl (360 $\mu \mathrm{mol} / \mathrm{L})$ under the age of 10 , - less than $12 \mathrm{mg} / \mathrm{dl}(720 \mu \mathrm{mol} / \mathrm{L})$ between the ages of $10-15$ and it is less than $15 \mathrm{mg} / \mathrm{dl}(900 \mu \mathrm{mol}$ / L) over the age of 15 .

Due to the limited nutrients consumed in infancy, difficulties are encountered in dietary intake of the recommended amount of phenylalanine. Cow milk or commercial foods can be used to meet the needs of phenylalanine in children who start supplementary feeding. However, the level of phenylalanine in cow milk is $180 \mathrm{mg} / 100 \mathrm{ml}$ and it is quite high (Evans et al., 2015) and phenylalanine amount also in UHT cow milk is $129 \mathrm{mg} / 100 \mathrm{ml}$ (Table 1).

The amount of PA that the patient should receive in the PKU following infancy should be met from natural protein sources such as low protein and low PA special products, cereals, vegetables and fruits. The reason that the requirement of phenylalanine varies according to the patient and life period depends on the presence of anabolism or catabolism. In the enzyme deficiency of patients in the catabolic period, tyrosine, an essential amino acid, must be given (Van Spronsen et al., 2017).

Table 1-Average amounts of phenylalanine in per 100 grams of some foods

\begin{tabular}{|ll|}
\multicolumn{1}{c|}{ Food } & Phenylalanine \\
\hline Pasta, low protein & $0 \mathrm{mg}$ \\
Adult human milk & $34 \mathrm{mg}$ \\
UHT cow milk (100ml) & $129 \mathrm{mg}$ \\
White bread & $429 \mathrm{mg}$ \\
Bonito (fish) & $694 \mathrm{mg}$ \\
Veal & $711 \mathrm{mg}$ \\
Chicken meat (thigh) & $733 \mathrm{mg}$ \\
Egg yolk & $874 \mathrm{mg}$ \\
Red lentils (dry) & $1507 \mathrm{mg}$ \\
Peas (dry) & $1104 \mathrm{mg}$ \\
Sweet corn & $118 \mathrm{mg}$ \\
\hline
\end{tabular}

(http://www.turkomp.gov.tr/, retrieved 23.01.2020)

\section{Other Nutrients}

Since studies have low n-3 and n-6 fatty acids in patients with PKU, these patients should be given a diet containing all fatty acids (Mahan \&Raymond, 2016). 
It is very important that the diet is rich in carnitine due to the low carnitine level in patients with PKU. The reasons for low carnitine in these patients are; dietary intake of carnitine, disruption of carnitine synthesis and metabolism in the body, impaired absorption from the small intestine (Deon et al., 2015).

In the dietary treatments of children with PKU; since natural protein sources containing trace elements and minerals are limited, deficiency in selenium, zinc, copper, iron and calcium is encountered.

In patients with PKU, serum alkaline phosphatase level, erythrocyte, leukocyte, zinc levels and the amount of zinc contained in the diet should be taken into account in determining zinc deficiency (Crujeiras et al,2015; Mahan \&Raymond, 2016). LPD / LPF (low protein drinks / low protein foods) foods containing calcium and iron should be used in bone and tooth development in children with PKU (Demirdas et al.,2015).

Since foods originating from animal origin and / or high protein are limited in PKU, vit B2, vit B3, vit B6, vit B12 and folic acid deficiencies and related findings can be seen in these patients (Kose \& Arslan, 2019).

\section{Special foods in PKU}

In nutritional therapy of phenylketonuria, multi-purpose medicinal products limited to protein and phenylalanine, rich in energy are used. These products differ in quantity and variety according to the daily needs of each patient. Following the start of the complementary feeding, children should be accustomed to them and the future rejection and reluctance about the product should be prevented (Pena et al., 2015).

\section{Artificial Sweeteners}

Aspartame should not be preferred in the use of artificial sweeteners. As a result of aspartame metabolism, it turns into $34 \%$ aspartic acid, $56 \%$ phenylalanine and $10 \%$ methanol. In case of a low energy diet in phenylketonuria, products that are flavored with aspartame should not be included (O'Sullivan et al., 2016).

The consumption of breastfeeding in PKU

Breast milk is the main food source of infancy. Few situations due to mother and baby require the baby to be deprived of breast milk. Breast milk contains a small amount of phenylalanine and tyrosine. (Sur Ünal \& Çifçili, 2019). As it can be seen in Table 1, although breast milk contains less phenylalanine than other foods, it can be helpful for healthcare professionals to provide milking or bottle by depending on the fact that the amount of phenylalanine taken by breastfeeding cannot be measured during the day (Köksal \& Gökmen Özel, 2019). Recently, breastfeeding has begun to replace the standard formula in patients with PKU. Recent studies have shown that babies who are breastfed with PKU do not differ significantly between. Contrarily, in another study, it was shown that serum phenylalanine levels are better in babies who are breastfed with phenylketonuria compared to those who are bottle-fed, and that breastfeeding positively affects weight gain in the first year of life in patients with PKU (Kose et al., 2018).

\section{Other Therapies}

While LNAA is transported through the blood-brain barrier, they share a common receptor. In the presence of higher levels of amino acid in the plasma and higher affinity for the carrier, the rate of transport of other amino acids is reduced. The high level of plasma phenylalanine reduces the uptake of LNAA by the brain and may increase the uptake of these amino acids in peripheral tissues. Increasing the LNAA concentration reduces the accumulation of phenylalanine in the brain by reducing the number of areas available for the transportation of phenylalanine. Although LNAA reduces plasma phenylalanine levels by inhibiting the transfer of phenylalanine in the intestinal blood barrier, the use of LNAA in the standard dietary restriction is unlikely to reduce plasma phenylalanine levels to the optimal target range. According to conclusion of study the P: T (Phe: Tyr) ratio is significantly dependent on dietary LNAA and plasma LNAA concentrations. In addition, in patients with PKU, the P: T ratio and valine may be effective clinical indicators in determining the metabolic balance of LNAA and the quality of diet LNAA (Hoeksma et al., 2009; Douglas et al., 2019).

Additionally, the other therapy in cofactor defects is Sapropterin (BH4) that is a cofactor and since BH4 is a necessary cofactor to demonstrate the activity of the hydroxylase enzyme, it has been tried to be considered as an alternative treatment to phenylalanine restriction in the diet. Treatment with sapropterin (a synthetic form of BH4) is used as an adjunctive therapy in people with some mild symptoms, but longer studies are needed on this subject (Lindegren et al., 2013).

It has an effect on increasing residual phenylalanine hydroxylase (PAH) activity and balancing phenylalanine levels in individuals with sensitive genotypes. There was a decrease in phenylalanine levels in children and adults receiving sapropterin, and those with symptoms of attention deficit hyperactivity disorder were found to improve. In other study with BH4 concluded " Even though the 48hour BH4 loading test has proven its efficacy in the past, a full week may be necessary to detect all responders. A threshold of $\geq 20 \%$ decrease within $48 \mathrm{~h}$ is not useful for predicting true BH4 responsiveness" (van Wegberg, et al., 2019).

\section{Conclusion}

PKU disease and requiring mostly life-long treatment significantly affect the quality of life of patients and their parents. In addition to the effect of the treatment, the social, psychological and economic burden of the patient is also very important. Despite the emergence of new treatments, the diet approach is the basis of PKU treatment. However, there are various difficulties faced by patients, healthcare professionals and the family in the implementation of nutritional therapy for these patients. Minimizing the negativities observed in nutrition therapy makes the treatment more effective. Problems experienced by the patient and his family (socioeconomic conditions, social environment and taste of the foods used, etc.) make it difficult to apply diet therapy. The most important difficulty in applying the nutritional treatment of the patient is that the tastes of the special products that should be given in this disease are bad and that the patient is reluctant to eat and feed. The patient, the dietician and the family have a great role in the achievement of the treatment. For this reason, with effective training methods to be given to the patient and his family, problems in the application of nutritional therapy and complications that may arise in case of non-application can be prevented to a great extent.The role and importance of the healthcare team, especially dietitians, in nutritional therapy is very important.The addition of phenylalanine nutrients to the healthy nutrition treatment planned by dieticians in appropriate sizes and development of different and alternative nutrition models to provide diversity will facilitate the perspective, compliance and hence the success of the patients with PKU and their families. Especially in infancy, the 
completion of neuromotor development, and the cognitive development required for the next period, the improvement of intelligence quotient (IQ) level and the acquisition of learning skills, have an important role in the early onset and continuity of this treatment. Based on all information and studies, the PKU diet and new and existing treatments are an important factor that positively affects the psychological, social and neurocognitive life of PKU patients.

\section{References}

Ahring, K., Bélanger-Quintana, A., Dokoupil, K., Gokmen Ozel, H., Lammardo, A. M., MacDonald, A., Motzfeldt, K., Nowacka, M., Robert, M., van Rijn, M., (2009). Dietary Management Practices in Phenylketonuria Across European Centres. Clinical Nutrition, 28(3), 231-236.

Azaripour, A., Abbasi, H., 2020. Effect of Type and Amount of Modified Corn Starches on Qualitative Properties of Low-Protein Biscuits for Phenylketonuria. Food Sci Nutr.8:281-290.

Bay, S. (2019). Bölgemizdeki Fenilketonüri Hastalığının ve Tedavisinin Ailelerin ve Fenilketonürili Çocukların Yaşam Kaliteleri Üzerine Olan Etkisinin Araştırılması (Uzmanlık Tezi). Akdeniz Üniversitesi, Antalya.

Blau, N., van Spronsen, FJ., Levy, HL., 2010. Phenylketonuria. Lancet, 376:1417-27.

Concolino, D., Mascaro, I., Moricca, M.T., Bonapace, G., Matalon, K., Trapasso, J., Radhakrishnan, G., Ferrara, C., Matalon, R., Strisciuglio, P., 2017. Long-Term Treatment of Phenylketonuria with a New Medical Food Containing Large Neutral Amino Acids. Eur J Clin Nutr, 71, 51-55.

Demirdas, S., Coakley, K.E., Bisschop, P.H., Hollak, C.E.M., Bosch, A.M., Singh, R.H.,2015. Bone Health in Phenylketonuria: A Systematic Review and Meta-analysis. Orphanet Journal of Rare Diseases, 10:17.

Deon, M., Landgraf, S.S., Lamberty, J.F., Moura, D.J., Saffi, J., Wajner, M., Vargas, C.R., 2015. Protective Effect of L-Carnitine On Phenylalanine-İnduced DNA Damage. Metab Brain Dis, 30, 925-933.

Douglas T.D., Nucci, A.M., Berry, A.M., Henes, S.T., Singh, R.H., 2019. Large Neutral Amino Acid Status in Association with P:T Ratio and Diet in Adult and Pediatric Patients With Phenylketonuria. JIMD Reports.;50:50-59.

Durrer, KE, Allen, MS, von Herbing I.H., (2017) Genetically Engineered Probiotic for The Treatment of Phenylketonuria (PKU); Assessment of a Novel Treatment in Vitro and in The Pahenu2 Mouse Model of PKU. PLoS ONE 12(5): e0176286.

Enacán, R.E., Miñana, M.N., Fernandez, L., Valle, M.G., Salerno, M., Fraga, C.I., Santos-Simarro, F., Prieto, L., Lapunzina, P., Specola, N., Chiesa, A.N., 2019. Phenylalanine Hydroxylase (PAH) Genotyping in PKU Argentine Patients. Journal of Inborn Errors of Metabolism \& Screening, Volume 7: e20190012.

Evans, S., Daly, A., Chahal, S., MacDonald, J., \& MacDonald, A. (2015). Food Acceptance and Neophobia in Children with Phenylketonuria: A Prospective Controlled Study. Journal of Human Nutrition and Dietetics, 29(4), 427-433.

Evans, S., Daly, A., Wildgoose, J., Cochrane, B., Chahal, S., Ashmore, C., Loveridge, N., MacDonald, A., (2019). Growth, Protein and Energy Intake in Children with PKU Taking a Weaning Protein Substitute in the First Two Years of Life: A Case-Control Study. Nutrients, 11, 552.

Herenger, Y., Maes, E., François, L., Pasco, J., Bouchereau, J., Pichard, S., de Baulny, H.O., Schiff, M., 2019. Determining factors of the Cognitive Outcome in Early Treated PKU: A Study of 39 Pediatric Patients. Molecular Genetics and Metabolism Reports 20:1004983.

Hoeksma, M., Reijngoud, D.J., Pruim, J., de Valk, H.W., Paans, A.M., vanSpronsen FJ., 2009. Phenylketonuria: High Plasma Phenylalanine Decreases Cerebral Protein Synthesis. Mol Genet Metab, 96:177-82.

http://www.turkomp.gov.tr/: retrieved 23.01.2020

Kose, E., Aksoy, B., Kuyum, P., Tuncer, N., Arslan, N., Ozturk, Y. (2018). The Effects of Breastfeeding in Infants with Phenylketonuria. Journal of Pediatric Nursing, 38, 27-32.

Kose, E., Arslan, N., 2019. Vitamin/mineral and Micronutrient Status in Patients with Classical Phenylketonuria. Clinical Nutrition, Volume 38, Issue 1.

Köksal, G., Gökmen Özel, H., 2019. Çocuk Hastalıklarında Beslenme Tedavisi. Hatiboğlu Yayınevi.

Levy, H., Lamppu, D., Anastosoaie, V., Baker, J.L., DiBona, K., Hawthorne, S., Lindenberger, J., Kinch, D., Seymour, A., McIlduff, M., Watling, S., Vockley, J., 2019. 5-Year Retrospective Analysis of Patients with Phenylketonuria (PKU) and Hyperphenylalaninemia Treated at Two Specialized Clinics. Molecular Genetics and Metabolism, https://doi.org/10.1016/j.ymgme.2019.12.007

Lichter-Konecki, U., Vockley, J., 2019. Phenylketonuria: Current Treatments and Future Developments. Drugs 79, $495-500$.

Lindegren M.L., Krishnaswami S., Reimschisel T., Fonnesbeck C., Sathe N.A., McPheeters M.L. (2012) A Systematic Review of BH4 (Sapropterin) for the Adjuvant Treatment of Phenylketonuria. JIMD Reports- Case and Research Reports, 109-119.

Liu, N., Huang, Q., Li, Q. Zhao, D., Li, X., Cui, L., Bai, Y., Feng, Y., Kong, X., 2017. Spectrum of PAH Gene Variants Among a Population of Han Chinese Patients with Phenylketonuria from Northern China. BMC Med Genet, 18, 108.

Mahan, LK., Raymond, JL., 2016. Krause's Food \& the Nutrition Care Process [14 ed.].

McPheeters, M.L., Lindegren, M.L., Sathe, N., Reimschisel, T., 2012. Adjuvant Treatment for Phenylketonuria: Future Research Needs: Identification of Future Research Needs from Comparative Effectiveness Review No. 56 [Internet], Rockville, Md, Agency for Healthcare Research and Quality (US).

Mitchell, J.J, Trakadis, Y.J, Scriver, C.R., 2011. Phenylalanine Hydroxylase Deficiency. Genet Med;13(8):697-707.

Ney, D.M, Gleason, S.T, van Calcar, S.C., MacLeod, E.L., Nelson, K.L., Etzel, M.R., Rice, G.M., Wolff, J.A., 2009. Nutritional Management of PKU with Glycomacropeptide from Cheese Whey. J Inherit Metab Dis, 32:32-39.

Ney, D.M., Blank, R.D., Hansen, K.E., 2014. Advances in the Nutritional and Pharmacological Management of Phenylketonuria. Curr Opin Clin Nutr Metab Care, 17(1): 61-68. 
O’Sullivan, A.J., Pigat, S., O’Mahony, C., Gibney, M. J., McKevitt, A. I., 2016. Probabilistic Modelling to Assess Exposure to Three Artificial Sweeteners of Young Irish Patients Aged 1-3 Years with PKU and CMPA. Food Additives \& Contaminants: Part A, $33(11), 1660-1671$.

Peate, Ian. (2020). Blood Spot Screening Programme for Newborns. British Journal of Healthcare Assistants Vol. 14 , No.1.

Pena, M.J., Almeida, M.F., van Dam, E. Ahring, K., Bélanger-Quintana, A., Dokoupil, K., Gokmen-Ozel, H., Lammardo, A.M., MacDonald, A., Robert, M., Rocha, J.C., 2015. Special Low Protein Foods for Phenylketonuria: Availability in Europe and an Examination of Their Nutritional Profile. Orphanet J Rare Dis 10, 162.

Rocha, J.C., MacDonald, A., 2016. Dietary İntervention in the Management of Phenylketonuria: Current Perspectives. Pediatric Health Med Ther.; 7: 155-163.

Strisciuglio, P., Concolino, D., 2014. New Strategies for the Treatment of Phenylketonuria (PKU). Metabolites, 4, $1007-1017$.

Sur Ünal, Ü., Çifçili, S.S., 2019. Emzirmede Bebek Açısından Kontrendikasyon Oluşturan Durumlar. Telatar B, editör. Aile Hekimliğinde Anne Sütünün Anne ve Bebek Sağlığı Açısından Önemi. 1. Bask1. Ankara: Türkiye Klinikleri; p.93-6.

Van Spronsen, F. J., van Wegberg, A.M.J., Ahring, K., Bélanger-Quintana, A., Blau, N., Bosch, A. M., Burlina, A., Campistol, J., Feillet, F., Gizewska, M., Huijbregts, S.C., Kearney, S., Leuzzi, V., Maillot, F., Muntau, A.C., Trefz, F.K., van rijn, M., Walter, J.H., MacDonald, A. 2017. Key European Guidelines for the Diagnosis and Management of Patients with Phenylketonuria. The Lancet Diabetes \& Endocrinology, 5(9), 743-756.

Van Wegberg, A.M.J., Evers, R.A.F., van Dam, E., de Vries, M.C., Janssen, M.C.H., Heiner-Fokkema, M.R., van Spronsen, F.J., 2019. Does the 48-hour BH4 loading test miss responsive PKU patients? Molecular Genetics and Metabolism., https://doi.org/10.1016/j.ymgme.2019.12.011.

Van Vliet, D., Annemiek, M.J., van Wegberg, Ahring, K., Bik-Multanowski, M., Casas, K., Didycz, B., Djordjevic, M., Hertecant, J.L., Leuzzi, V., Mathisen, P., Nardecchia, F., Powell, K.K., Rutsch, F., Stojiljkovic, M., Trefz, F.K., Usurelu, N., Wilson, C., van Karnebeek, C.D., Hanley, W.B., van Spronsen, F.J., 2019. Untreated PKU Patients without Intellectual Disability: What Do They Teach Us? Nutrients, 11, 2572. 